Egypt. J. of Nutrition and Health Vol. 15 No. 1 January (2020)

\title{
Assessment of Nutritional Status of Women Suffering from Thyroid Dysfunction and Osteoporosis
}

\author{
Hoda S. Ibrahim*, Mohamed MagdyGhit ${ }^{\star \star}$ and Niveen M. Abd El-Azeem* \\ *Nutrition and Food Science Department, \\ Faculty of Home Economics, Helwan University, \\ ${ }^{* *}$ Rheumatology and Rehabilitation Department, Faculty of Medicine, Al-Azhar \\ University, Cairo, Egypt.
}

\begin{abstract}
Osteoporosis and thyroid disorders are common diseases in the elderly. The aim of the present study was to assess the nutritional status of women suffering from thyroid dysfunction and osteoporosis. This work was carried out on a number of 70 women (40 hyperthyroidism and 30 hypothyroidism). They were 50-60 years old. All patients were selected from the (El-Hussein, Sayed Galal and El Zaharaa) hospitals, Cairo, Egypt. Data were collected by interviewing patients. Anthropometric measurements were performed for all patients. Nutritional assessments were collected using questionnaire and 24-hr recall method for 3 days as well as food frequency questionnaire. There sults revealed that patient's weight with hypothyroidism was higher than patients with hyperthyroidism. Although, the mean values of energy, macronutrients, minerals and vitamins for hyperthyroidism and hypothyroidism were not significantly different, except vitamin A which was significantly high.Our study also revealed that the mean values of energy and macronutrients intake were greater than the recommended dietary allowance (RDA) of the tested patients. On the contrary, the minerals (copper, magnesium and calcium) in take of all women under investigation showed low values compared with the RDA.The intake of phosphorus and zinc is close to RDA. However, their intake of iron exceeded the RDA levels. Vitamins $A, C, B_{1}$ and $B_{2}$ were lower than the RDA levels. The mean values of thyroid hormones and calcium concentration in the blood are within the normal range,although there were significant differences in the blood concentration of thyroid hormones between hyperthyroidism and hypothyroidism. This study recommends nutrition education program for the women suffering from thyroid dysfunction and osteoporosis. Also, proper dietary habits should start early and continue through life.
\end{abstract}

Keywords:Nutritional Assessment, Thyroid Dysfunction, Osteoporosis, Nutrients Intake.

\section{Introduction}

Thyroid hormones (THs) are essential for normal metabolism and have important effects on skeletal development, linear growth and the maintenance of adult bone mass and strength (Williams and Bassett, 2018). The essential requirement for thyroid hormones during linear growth and skeletal maturation is well established and has been recognized for long time (Bassett and Williams, 2016). Any changes of normal thyroid function in euthyroid individuals are related to body weight variations. Thyroid stimulating hormones (TSH) directly affects the remodeling of bone through TSH receptor found on osteoblast and osteoclast precursor cells (Bhatnagaret al., 2017). Maintaining normal thyroid function is important for achieving appropriate bone development and peak bone mass in young age, 


\section{Hoda S. Ibrahim, et al}

as well as for regulating the rate of bone turnover in adults. It is well known that bone mineralization is reduced and that the rate of bone turnover is increased in thyrotoxicosis, leading to an increased risk of hip fractures (Lee et al., 2016).

Osteoporosis (OP) is one of the chronic diseases affecting individuals' lives, especially women (Sharifiet al., 2017). It is the most common bone disease, and it is characterized by low bone mass, destruction of bone microstructure, which leads to increased bone fragility and the risk of bone fracture(Zhao et al., 2020). It is also an important cause for increased morbidity and mortality in postmenopausal women and elderly men (Kapooret al., 2017).Sometimes it is called the "silent disease", as there may be no noticeable symptoms associated with bone loss, because it can be present without any symptoms until bone breaks. The symptom associated with osteoporotic fractures usually is pain; the position of the pain depends on the location of the fracture (Elbossaty, 2017).

\section{Patients and Methods}

Patients:

Sample of 70 women(40 hyperthyroidism and 30 hypothyroidism), their age ranged from 50 60 years old. They were suffering from thyroid dysfunction and osteoporosis according to the clinical examination and laboratory investigation. Cases with other chronic diseases were excluded. All patients were selected from the Hospitals (El Hussein, SayedGalal and El Zaharaa) Cairo, Egypt.

Methods:

Personal data:

Information on personal data related to name, age, residence, occupation and phone number were collected.

Anthropometric Measurements:

Height and Weight:

The height of the patients was measured using the method described by Jellife (1966). Weight was measured without shoes and in light clothing by using common health balance (FerroLuzziet al., 1992).

\section{Body mass index:}

Body mass index (BMI) is a measure for indicating nutritional status in adults. (BMI) is a simple index of weight- for-height. It has been calculated using the formula: BMl $\left(\mathrm{Wt}(\mathrm{Kg}) / \mathrm{Ht}\left(\mathrm{m}^{2}\right)\right)$ (WHO, 2004).

Nutritional assessment:

24-Hr Recall:

Food intake of each subject was estimated for three days per week using 24-hour recall method. Nutritive values of the consumed foods were calculated using Egyptian food composition tables of National Nutrition Institute (2006).

Food Frequency Questionnaire (FFQ) is designed to assess habitual diet by asking about the frequency with which specific food items are consumed during the period(day or month) (Willett and Lenart, 1998). 


\title{
Egypt. J. of Nutrition and Health Vol. 15 No. 1 January (2020)
}

\author{
Clinical assessment: \\ Clinical examination and laboratory investigations were conducted blood samples were \\ collected and serum were separated and kept frozen till analysis. Biochemical analyses were \\ conducted in Al-Hussein hospital.
}

\section{Laboratory Assessment:}

Thyroid hormones: free thyroxine (FT4), free triiodothronine (FT3) and thyroid stimulating hormone levels (TSH)(Caldwell et al., 1985).Calcium concentration(Bold, 1970)

\section{Statistical analysis:}

Statistical analysis was done using computer software system social sciences (SPSS) version 21. The proportions were compared using $X 2$ test. In quantitative variables, Comparison between two groups was done by $t$ test. All data were presented as mean \pm standard deviation. $P$ value less than 0.05 is significant level and less than 0.001 is highly significant level (Armitage and Berry, 1987).

\section{Results and Discussion}

Results in Table (1) show the distribution of height for the patients suffering from hyperthyroidism and hypothyroidism. It was observed that the hyperthyroidism their height was $159 \mathrm{~cm}$, while the hypothyroidism was $161.3 \mathrm{~cm}$. It was observed that difference was not significant. Concerning body weight, data revealed that patient's weight with hypothyroidism $(90.5 \mathrm{~kg})$ was higher than patients with hyperthyroidism $(81.1 \mathrm{~kg})$ and the difference was significant $(P<0.05)$. Although, the mean values of energy, macronutrients, minerals and vitamins for hyperthyroidism and hypothyroidism were not significantly different, except vitamin A which was highly significantly different. Our results are in agreement with the findings of Gupta et al., (2015) reported that people with hypothyroidism were characterized by increased weight. Thereby it is concluded that Thyroid Stimulating Hormone affects the body mass index in women suffering from hypothyroidism.In addition, Janssen et al., (2015) demonstrated that subclinical hypothyroidism and hypothyroidism are more common in obese patients than normal-weight patients are.

Results of this study; Table (2) shows the distribution of body mass index (BMI) for the patients suffering from regarding of hyperthyroidism and hypothyroidism. Data revealed that the highest percentage of BMI was obese $83.3 \%$ for hypothyroidism and $62.5 \%$ for hyperthyroidism. These results are in agreement with the finding of Solankiet al., (2013) and Al-Musa, (2017) they concluded that a positive association between serum TSH level and BMI.In the same line a study by Hamlaouiet al., (2018) sharedit total 86 patients suffering from thyroid disorders; found that patients with hypothyroidism had significantly higher level of BMI and obesity. Hyperthyroidism patients had lower level of BMI.

Results in Table (3) show mean values of energy and macronutrients intake by patients in relation to the recommended dietary allowance (RDA) of the tested women with hyperthyroidism and hypothyroidism. Data revealed that the mean value of energy intake for hyperthyroidism (1472.3 \pm $407.7 \mathrm{kcal}$ ) was greater than the mean value for hypothyroidism (1361.2 $\pm 454.3 \mathrm{kcal})$. However, there were not significant differences in energy intake between hyperthyroidism and hypothyroidism.

Data also revealed that the mean value of energy intake for all patients $(1424.7 \pm 428.7 \mathrm{kcal})$ was greater than the value of RDA level $(1066.8 \mathrm{kcal})$. This increase in the daily intake compared with 


\section{Hoda S. Ibrahim, et al}

the RDA was highly significant.Zabriskieet al., (2019) have stated that energy is required for all bodily functions. Humans take energy in the form of protein, carbohydrate and fat (Hill et al., 2012).When daily energy intake is in excess of energy expenditure (EE) a state of positive energy balance occurs. $A$ small cumulative impact of sustained positive energy balance results in weight gain and obesity(Markwaldet al., 2013), thus the patients in our study could be exposed to obesity.

The mean value of protein intake for both hyperthyroidism and hypothyroidism was in the same average $(57.2 \pm 15.8 \mathrm{~g}$ vs. $56.2 \pm 16.4 \mathrm{~g}$, respectively).It was noticed that there were not significant differences in protein intake between hyperthyroidism and hypothyroidism. Mean value of daily intake of protein for all patients was higher than the RDA level as shown in Table (3) (56.8 \pm 15.9 vs. $40 \mathrm{~g}$ ). Oh and No, (2017) illustrated (from the Korean National Health and Nutrition Examination Survey, using men and women aged 51-70 years for women and $\geq 71$ years for men) that inadequate intake was higher in women and super-aging groups than others, which contradict our results. These conflicts in the results may be due to the differences in the average of the age of the tested subjects as well as the environment of conducting the study. Age-related endocrine and metabolic alterations induce body composition changes including progressive loss of muscles and bone mass and acquisition of fat mass. However, protein intake of the elderly has shown beneficial effects on osteoporosis prevention (Kwon et al., 2020).Adequate dietary protein intake is crucial for muscle protein synthesis to preserve muscle mass and limit the risk of disability associated with age. Higher dietary protein intake is associated with higher physical performance (Mishra et al., 2018), greater muscle mass and strength, both in postmenopausal women and in young. In older people with osteoporosis, increased levels of protein intake are associated with higher bone mineral density (BMD), a slower rate of bone loss and a reduced risk of hip fracture (Rizzoli et al., 2014).Therefore, it appears that the increased level of protein in our study could be beneficial to the tested subjects.

Concerning fat intake, results in the same table shows that the mean values of fat intake for both hyperthyroidism and hypothyroidism were very close $(42.0- \pm 15.9 \mathrm{~g}$ vs. $40.6 \pm 19.1 \mathrm{~g}$, respectively). Concerning fat intake, results in the same table shows that the mean value of daily intake of fat for all patients $(41.4 \pm 17.2 \mathrm{~g})$ was greater than the RDA $(29.6 \mathrm{~g})$. This finding is in agreement with the finding by Politoet al., (2005)using total of 387 healthy middle-aged women (55$70 y$ ) and older men (70-87y). A high fat intake of total energy was observed in all examined subjects. Dietary fat plays a major role in human nutrition and serves many essential functions. Dietary fat can stimulate or inhibit intestinal calcium (Ca) absorption depending upon the type and amount of fat intake. High fat diets may reduce Ca absorption by forming insoluble Ca soaps (Wang et al., 2016).

The mean value of carbohydrate intake for hyperthyroidism (215.9 $\pm 65.3 \mathrm{~g})$ was greater than the mean value for hypothyroidism $(191.7 \pm 68.3 \mathrm{~g})$. It was observed that there were no significant differences in carbohydrate intake between hyperthyroidism and hypothyroidism. The mean value of daily intake of carbohydrate for all patients was $205.6 \pm 67.2 \mathrm{~g}$ as shown in Table (3). It could be noticed that was greater than the RDA values $(160 \mathrm{~g})$ with about $39.8 \%$. Our results are in agreement with the findings of Sakuraiet al., (2018) who showed from the National Health and Nutrition Survey (NHNS) using a total of 2,637 participants (1,145 men and 1,492 women) that they had a carbohydrate intake that exceeded the RDA level.In conclusion, our results revealed that although the mean values of energy and macronutrients intake for hyperthyroidism compared with hypothyroidism of the tested patients were higher than the RDA level, but the difference is not significantly.

Results in Table (4) showed the mean values of minerals intake by patients in relation to the recommended dietary allowance (RDA) of the tested women with hyperthyroidism and hypothyroidism. 


\section{Egypt. J. of Nutrition and Health Vol. 15 No. 1 January (2020)}

The mean value of calcium intake for hyperthyroidism $(499.1 \pm 215.1 \mathrm{mg})$ was greater than the mean value for hypothyroidism $(476.4 \pm 139.7 \mathrm{mg})$. It was observed that there were no significant differences in calcium intake between hyperthyroidism and hypothyroidism. For all patients, data revealed that the mean value of daily intake of calcium $(489.4 \pm 185.7 \mathrm{mg}$ ) was less than the RDA level (1200 mg). Our result was in agreement with the findings of Kim et al., (2014) who found that calcium intake was less than the recommended dietary allowance (RDA) using a total of 3448 men and 3812 women older than 50 years. They concluded that low calcium intake was significantly related with low body mass density (BMD) and increased risk of osteoporosis. Vannucciet al., (2018) mentioned that calcium is essential element that plays numerous biological functions in the human body, of which one of the most important element in skeleton mineralization. Bone is a mineralized connective tissue in which calcium represents the major component, conferring bone strength and structure. Proper dietary calcium intake is important for bone development and metabolism.

In the same Table (4); the mean value of phosphorus intake for hyperthyroidism (734.5 \pm $218.6 \mathrm{mg}$ ) was greater than the mean value in case hypothyroidism (691.8 $\pm 188.4 \mathrm{mg})$. However, It was noticed that there were no significant differences in phosphorus intake between the two groups.For all patients the mean value of daily intake of phosphorus $(716.2 \pm 205.9 \mathrm{mg})$ was very close to the RDA value (700 mg). Farrow and White, (2010) illustrated that phosphorus is important for patients due to the maintenance of appropriate phosphorus homeostasis. In addition, it is critical for the well-being of the organism and for an optimal calcium-phosphate product for the mineralization of bone without its deposition in vascular and other soft tissues. Table (4) also shows that the mean value of magnesium intake for hyperthyroidism $(81.9 \pm 31.0 \mathrm{mg})$ was greater than the mean value for hypothyroidism $(79.8$ $\pm 26.9 \mathrm{mg})$ un-significantly. For all patients, the mean value of daily intake of magnesium(81.0 \pm $29.1 \mathrm{mg}$ ) was less than the RDA value $(320 \mathrm{mg})$. In a study by Orchard et al., (2014) using 73,684 postmenopausal women enrolled in the women's health initiative observational study, they concluded that lower magnesium intake is associated with lower bone mineral density of the hip and whole body. In the same line a study by Sharma et al., (2016) using 68 post-menopausal women, 48-75 years of age, was having osteoporosis and osteopenia. Concluded that osteoporosis is characterized by a lower concentration of magnesium. Therefore, the dietary intake of magnesium supplement may be useful in reducing the adverse effect of osteoporosis.

Concerning iron intake, mean value of iron intake for hyperthyroidism $(11.1 \pm 3.4 \mathrm{mg})$ was equal to the mean value for hypothyroidism and the mean value for all patients $(11.1 \pm 3.4 \mathrm{mg})$ but was greater than the RDA value $(8 \mathrm{mg})$. It was noticed that there were not significant differences in iron intake between hyperthyroidism and hypothyroidism. In a study by Yamasaki and Hagiwara, (2009) they found that iron over load might give rise to osteoporosis by inhibiting osteoblast proliferation and differentiation. In the same line a study by Messer et al., (2009) provided evidence that iron overload alters iron metabolism and suppresses differentiation and function of cells in the osteoblast lineage associated with increased apoptosis.Baloghet al., (2018) mentioned that iron overload as well as iron deficiency disrupts the delicate balance between bone destruction and production, via influencing osteoclast and osteoblast differentiation as well as activity, which suggested that balanced bone homeostasis, requires optimal not too low, not too high iron levels.

As shown in Table (4), the mean value of zinc intake for hyperthyroidism $(7.9 \pm 2.2 \mathrm{mg})$ was the same as the mean value for hypothyroidism as well as the mean value for all patients $(7.9 \pm 2.2$ $\mathrm{mg}$ ). The RDA value is $8 \mathrm{mg}$ per day. It was noticed that there were no significant differences in zinc intake between hyperthyroidism and hypothyroidism. There is an important relation between thyroid 


\section{Hoda S. Ibrahim, et al}

hormones and zinc. Low levels of Zinc are associated with hypothyroidism and high levels with hyperthyroidism (Baltaciet al., 2013).

Regarding cupper intake for hyperthyroidism it was less than the mean value for hypothyroidism patients $(0.5 \pm 0.2 \mathrm{mg}$ vs. $0.6 \pm 0.2 \mathrm{mg}$, respectively). However, it was un-significantly compared with the corresponding values of the RDA $(0.900 \mathrm{mg})$.In a study by Quet al., (2018) found that serum $\mathrm{Cu}$ levels are critically important for bone health. Lower serum $\mathrm{Cu}$ levels are significantly associated with decreased bone mineral density (BMD) in the total femur and femoral neck. Pepa and Brandi, (2016) mentioned that postmenopausal women with a high dietary $\mathrm{Ca}$ intake combined with a high serum $\mathrm{Cu}$ level had a greater lumbar bone density than women with low $\mathrm{Ca}$ intake and low serum copper.

Results in Table (5) showed the mean values of vitamins intake by patients in relation to the recommended dietary allowance (RDA) of the tested women with hyperthyroidism and hypothyroidism. The mean value of vitamin A intake for hyperthyroidism $(152.1 \pm 132.0 \mu \mathrm{g})$ was highly significant greater than the mean value for hypothyroidism $(1089.5 \pm 2063.5 \mu \mathrm{g})$. Haugen, (2019) found that the patients with hyperthyroidism were successfully treated with high dose of vitamin A which lead to decreased symptoms of hyperthyroidism as well as decreased metabolic rate. Farhangiet al., (2012) found that vitamin A supplementation might reduce the risk of subclinical hypothyroidism in premenopausal women.

Mean value of daily intake of vitaminA for all patients $(538.0 \pm 1393.5 \mu \mathrm{g})$ was less than of the RDA value $(3000 \mu \mathrm{g})$ as shown in the same table.Our results are in agreement with the finding of Han et al., (2005) who have shown in dietary survey that was performed to assess the nutritional status and dietary intake of the Korean and Han nationality elderly in Yanji that the daily intake of calcium, vitamin $A$ and vitamin $B_{2}$ in elderly were less than the recommended nutrient intake.

Results of the same Table (5) show that the mean value of vitamin C intake for hyperthyroidism $(29.5 \pm 34.7 \mathrm{mg})$ was less than the mean value for hypothyroidism (51.2 \pm 58.6 $\mathrm{mg}$ ).Concerning the intake of vitaminC for all patients, it was less than the level of that vitamin compared to the recommended dietary allowance (RDA) $(38.9 \pm 47.5 \mathrm{mg}$ vs. $75 \mathrm{mg}$, respectively).Our results are in agreement with the finding of study by Pignotti et al., (2015) they compared and evaluated the dietary quality of young and older sedentary Mexican-American women. They illustrated that over $60 \%$ of all participants had an intake below recommendations for vitamin C. In another study, Kim et al., (2015) derived the data from the Fourth Korean National Health and Nutrition Examination Survey using 1,196 postmenopausal women aged 50 years and older. They concluded that dietary vitamin $\mathrm{C}$ intake was positively associated with bone mineral density in postmenopausal women, and inadequate vitamin $\mathrm{C}$ intake could increase the risk of osteoporosis.

Results in Table (5) show that the mean value of vitamin $B_{1}$ intake for hyperthyroidism, hypothyroidism and all patients $(0.7 \pm 0.3 \mathrm{mg}$ vs. $0.7 \pm 0.3 \mathrm{mg}$ and $0.7 \pm 0.3 \mathrm{mg}$, respectively) were equal .It is obvious that there were not significant differences in vitamin $B_{1}$ intake between hyperthyroidism and hypothyroidism. The mean value of vitamin $B_{2}$ for hyperthyroidism $(0.6 \pm 0.4 \mathrm{mg})$ was less than the mean value for hypothyroidism $(0.8 \pm 0.6 \mathrm{mg})$. However, it was not significantly differed between hyperthyroidism and hypothyroidism. Daily intake of vitamin $B_{1}$ and vitamin $B_{2}$ were lower than the RDA levels $(0.7 \pm 0.3 \mathrm{mg}$ vs. $1.1 \mathrm{mg})$ and $(0.7 \pm 0.5 \mathrm{mg}$ vs. $1.1 \mathrm{mg})$, respectively. Ma et al., (2020) found that thiamine had inhibitory effect on osteoclast differentiation, and its inhibitory role on osteoclast differentiation is in a dose-dependent way. Yazdanpanahet al., (2007) concluded that 


\section{Egypt. J. of Nutrition and Health Vol. 15 No. 1 January (2020)}

increased dietary riboflavin and pyridoxine intake were associated with higher femoral neck bone mineral density. Dai and Koh, (2015) found that inadequate B vitamin intake has been reported among hip fracture patients. Kim et al., (2015) using data from a nationally representative sample of Korean menopausal women; participants consuming less protein, vitamin $B_{2}$, or vitamin $C$ than the estimated average requirement showed higher odds of having osteoporosis.

Results in Table (6) show the correlation coefficient of calcium intake and food frequency intakes of some food items. Data revealed that there was a positive correlation between calcium and fish, shrimp, liver, eggs, milk full cream, skimmed milk, milk powder, cheeses such as gooda, \& cheddar, yogurt, butter, cream, green beans, cabbage, bananas, strawberries, dried apricots, soft drinks and cocoa. However, results in the same table indicated that there was a negative correlation between calcium and cheese mozzarella, olive oil, butter, mallow, cauliflower, dried fig, tea, coffee and nescafe.It was observed that there was significant correlation coefficient between calcium and skimmed milk. The beneficial effects of milk or dairy products on bone health show a significant inverse association between dairy food intake and bone turnover markers and a positive association with bone mineral content (Rizzoli, 2014). Skimming method increases the concentration of mineral nutrients, which is especially remarkable in calcium contained in skimmed milk powder. In yogurt, addition of dried milk or evaporated milk appreciably increases the mineral content (Closaet al., 2003). Yamada et al., (2013) reported that increase in skimmed milk intakes brings positive calcium balances. Chee et al., (2003) recommend obtaining adequate calcium from low-fat milk and its products and other calcium-rich food sources to prevent osteoporosis.

In the same Table (6), it is observed that there was a significant correlation coefficient between calcium and yogurt intake.In study by Burckhardt, (2015) in postmenopausal women with a low dietary calcium intake of $<600 \mathrm{mg}$ per day, showed that three servings of yogurt lowered $\mathrm{N}$-telopeptide, a marker of bone resorption, to $22 \%$ lower values than the control snack. This is mainly a calcium effect. The probiotics in yogurt enhance calcium absorption and have an additional bone effect. Sahniet al., (2013) concluded that milk and yogurt intakes were associated with hip but not spine bone mineral density (BMD).

Data showed that there was a significant correlation coefficient between calcium and bananas (Table 6). Weaver (2013) illustrates the protective effect of adequate dietary potassium on age-related bone loss accordingly, alkaline potassium salts produced from metabolizing fruits and vegetables or potassium supplements are thought to protect against bone resorption for $\mathrm{pH}$ homeostasis.Potassium intake has been associated with reduced urinary calcium excretion.Kong et al., (2017) concluded that dietary potassium reduces calcium loss from the bone, leading to beneficial effect on bone mineral density. It was associated with improved bone mineral density in older men and postmenopausal women.

Results in Table (7) show mean values of some hormones and of calcium concentration in the blood of hyper and hypothyroidism patients. Results of thyroid stimulating hormone levels (TSH), free triiodothronine (FT3) and free thyroxine (FT4) for hyperthyroidism and hypothyroidism were within the normal range. Concerning TSH level in the blood,results recorded $0.7 \pm 0.8 \mathrm{ulU} / \mathrm{ml}$ for hyperthyroidism patients and $3.8 \pm 2.9 \mathrm{ulU} / \mathrm{ml}$ for the hypothyroidism. Data ofFT3 concentration in the blood was higher significantly in the hyperthyroidism compared to the hypothyroidism patients $(3.9 \pm 1.1 \mathrm{Pg} / \mathrm{ml}$ and $2.4 \pm$ $1.0 \mathrm{Pg} / \mathrm{ml}$, respectively) although both were in the normal range. Concerning the FT4 concentration in the blood results,showed the same trends $(1.5 \pm 0.5 \mathrm{ng} / \mathrm{dl}$ forhyperthyroidism and $1.0 \pm 0.2 \mathrm{ng} / \mathrm{dl}$ for hypothyroidism).Our results are in agreement with Nygaard (2015) who reported that hyperthyroidism 


\section{Hoda S. Ibrahim, et al}

is characterised by high levels of serum thyroxine (T4), high levels of serum triiodothyronine (T3), or both, and low levels of thyroid-stimulating hormone (TSH). On the other hand, Calsolaroet al.,(2018) reported that hypothyroidismis characterized by the increase in thyroid-stimulating hormone (TSH) values, accompanied by reduced circulating free triiodothyronine (FT3) and free thyroxine (FT4).In the same table results shows mean values of calcium in the blood. Results of calcium concentration in the blood were $8.8 \pm 0.9 \mathrm{mg} / \mathrm{dl}$ for hyperthyroidism and $8.9 \pm 0.8 \mathrm{mg} / \mathrm{dl}$ for hypothyroidism. It is clear that blood calcium level is within the normal range. However, the patient's daily intake of calcium was less than the recommended dietary allowance (Table 4). This result may be due to that most of the cases are having medicine for thyroid dysfunction and calcium supplements.

Results of Table (7) concluded that the mean values of thyroid hormones and calcium concentration in the blood are within the normal range, although there were highly significant difference in the blood concentration of thyroid hormones between hyperthyroidism and hypothyroidism.

Table (1):

Distribution of Anthropometric Measurements (Height and Weight) for Patients Suffering fromHyperthyroidism and Hypothyroidism.

\begin{tabular}{c|c|c|c}
\hline \multirow{2}{*}{ Groups } & Hyperthyroidism $(\mathrm{n}=40)$ & $\begin{array}{c}\text { Hypothyroidism } \\
(\mathrm{n}=30)\end{array}$ & \multirow{2}{*}{ Pvalue } \\
\cline { 2 - 3 } & Mean $\pm \mathrm{SD}$ & Mean \pm SD & 0.106 \\
\hline Height $(\mathrm{cm})$ & $159.0 \pm 5.5$ & $161.3 \pm 6.6$ & $0.002^{*}$ \\
\hline Weight $(\mathrm{kg})$ & $81.1 \pm 10.5$ & $90.5 \pm 14.3$ & ${ }^{*}$
\end{tabular}

All data presented as mean \pm standard deviation.

${ }^{*} \mathrm{P}<0.05$ = significant.

Table (2):

Distribution of Body Mass Index (BMI) for Patients Suffering fromHyperthyroidism and Hypothyroidism.

\begin{tabular}{l|c|c|c|c|c|r|r}
\hline \multirow{2}{*}{ Groups } & \multicolumn{2}{|c|}{$\begin{array}{c}\text { Hyperthyroidism } \\
(\mathrm{n}=40)\end{array}$} & \multicolumn{2}{c|}{$\begin{array}{c}\text { Hypothyroidism } \\
(\mathrm{n}=30)\end{array}$} & \multicolumn{2}{c}{$\begin{array}{c}\text { Total } \\
(\mathrm{n}=70)\end{array}$} & \multirow{2}{*}{ Pvalue } \\
\cline { 2 - 7 } & No & $\%$ & No & $\%$ & No & $\%$ & \\
\hline BMI & & & & & & & \\
Normal & 1 & 2.5 & 1 & 3.4 & 2 & 2.9 & \multirow{2}{*}{0.122} \\
Overweight & 14 & 35.0 & 4 & 13.3 & 18 & 25.7 & \\
Obese & 25 & 62.5 & 25 & 83.3 & 50 & 71.4 & \\
\hline
\end{tabular}

Table (3):

Mean Values of Energy and Macronutrients Intake by Patients in Relation to the Recommended Dietary Allowance (RDA) of the Tested Women withHyperthyroidism (Hyper) and Hypothyroidism (Hypo).

\begin{tabular}{|c|c|c|c|c|c|c|}
\hline \multirow{2}{*}{ Nutrients } & RDA & Hyper(40) & Нypo(30) & Total(70) & \multirow{2}{*}{ T-test } & \multirow{2}{*}{$\begin{array}{c}P \\
\text { value }\end{array}$} \\
\hline & value & Mean \pm SD & Mean \pm SD & Mean \pm SD & & \\
\hline Energy (kcal) & 1066.8 & $1472.3 \pm 407.7$ & $1361.2 \pm 454.3$ & $1424.7 \pm 428.7$ & -0.985 & 0.325 \\
\hline Protein (g) & 40.0 & $57.2 \pm 15.8$ & $56.2 \pm 16.4$ & $56.8 \pm 15.9$ & -0.570 & 0.569 \\
\hline Fat (g) & 29.6 & $42.0 \pm 15.9$ & $40.6 \pm 19.1$ & $41.4 \pm 17.2$ & -0.344 & 0.731 \\
\hline Carbohydrate (g) & 160.0 & $215.9 \pm 65.3$ & $191.7 \pm 68.3$ & $205.6 \pm 67.2$ & -1.495 & 0.135 \\
\hline
\end{tabular}


Egypt. J. of Nutrition and Health Vol. 15 No. 1 January (2020)

Table (4):

Mean Values of MineralsIntake by Patients in Relation to Recommended Dietary Allowance (RDA) of the Tested Women with Hyperthyroidism (Hyper) and Hypothyroidism (Hypo).

\begin{tabular}{|c|c|c|c|c|c|c|}
\hline \multirow{2}{*}{ Minerals } & \multirow{2}{*}{$\begin{array}{l}\text { RDA } \\
\text { value }\end{array}$} & Hyper(40) & Hypo(30) & Total(70) & \multirow{2}{*}{ T-test } & \multirow{2}{*}{$\begin{array}{c}\mathrm{P} \\
\text { value }\end{array}$} \\
\hline & & Mean \pm SD & Mean \pm SD & Mean \pm SD & & \\
\hline Calcium (mg) & 1200 & $499.1 \pm 215.1$ & $476.4 \pm 139.7$ & $489.4 \pm 185.7$ & -0.059 & 0.953 \\
\hline Phosphorus (mg) & 700 & $734.5 \pm 218.6$ & $691.8 \pm 188.4$ & $716.2 \pm 205.9$ & -0.854 & 0.393 \\
\hline Magnesium (mg) & 320 & $81.9 \pm 31.0$ & $79.8 \pm 26.9$ & $81.0 \pm 29.1$ & -0.404 & 0.687 \\
\hline Iron (mg) & 8 & $11.1 \pm 3.4$ & $11.1 \pm 3.4$ & $11.1 \pm 3.4$ & 0.000 & 1.000 \\
\hline Zinc (mg) & 8 & $7.9 \pm 2.2$ & $7.9 \pm 2.2$ & $7.9 \pm 2.2$ & -0.273 & 0.785 \\
\hline Copper (mg) & 0.900 & $0.5 \pm 0.2$ & $0.6 \pm 0.2$ & $0.5 \pm 0.2$ & -0.018 & 0.986 \\
\hline
\end{tabular}

All data presented as mean \pm standard deviation.

Table (5):

Mean Values of Vitamins Intake by Patients in Relation to Recommended Dietary Allowance (RDA) of the Tested Women with Hyperthyroidism (Hyper) and Hypothyroidism (Hypo).

\begin{tabular}{|c|c|c|c|c|c|c|}
\hline \multirow{2}{*}{ Vitamins } & RDA & Hyper(40) & Нyро(30) & Total(70) & \multirow{2}{*}{ T-test } & \multirow{2}{*}{$\begin{array}{c}P \\
\text { value }\end{array}$} \\
\hline & value & Mean \pm SD & Mean \pm SD & Mean \pm SD & & \\
\hline Vitamin $A(\mu g)$ & 3000 & $152.1 \pm 132.0$ & $1089 \pm 2063$ & $538.0 \pm 1393$ & -3.626 & $0.0001^{*}$ \\
\hline Vitamin C (mg) & 75 & $29.5 \pm 34.7$ & $51.2 \pm 58.6$ & $38.9 \pm 47.5$ & -1.731 & 0.083 \\
\hline Vitamin $B_{1}(\mathrm{mg})$ & 1.1 & $0.7 \pm 0.3$ & $0.7 \pm 0.3$ & $0.7 \pm 0.3$ & -0.504 & 0.614 \\
\hline Vitamin B2 (mg) & 1.1 & $0.6 \pm 0.4$ & $0.8 \pm 0.6$ & $0.7 \pm 0.5$ & -1.092 & 0.275 \\
\hline
\end{tabular}

All data presented as mean \pm standard deviation.

${ }^{*} \mathrm{P}<0.001=$ Highly significant. 
Hoda S. Ibrahim, et al

Table (6):

Correlation Coefficient between Calcium and Some Foods Frequency Intake.

\begin{tabular}{l|c|c}
\hline \multirow{2}{*}{ Foods } & \multicolumn{2}{|c}{ Calcium Intake } \\
\cline { 2 - 3 } & $\mathrm{r}$ & $\mathrm{P}$ \\
\hline Fish & 0.045 & 0.754 \\
Shrimp & 0.023 & 0.918 \\
Liver & 0.191 & 0.231 \\
Eggs & 0.141 & 0.266 \\
Milk full cream & 0.140 & 0.591 \\
Skimmed milk & 0.534 & $0.002^{*}$ \\
Powder milk & 0.362 & 0.098 \\
Cheese gooda & 0.140 & 0.632 \\
Cheese cheddar & 0.353 & 0.107 \\
Cheese mozzarella & -0.258 & 0.235 \\
Yogurt & 0.416 & $0.002^{*}$ \\
Olive oil & -0.106 & 0.666 \\
Cream & 0.122 & 0.736 \\
Butter & -0.207 & 0.321 \\
Mallow & -0.081 & 0.677 \\
Green beans & 0.244 & 0.075 \\
Cauliflower & -0.20 & 0.147 \\
Cabbage & 0.026 & 0.842 \\
Bananas & 0.380 & $0.002^{*}$ \\
Strawberries & 0.261 & 0.118 \\
Dried figs & -0.069 & 0.791 \\
Dried apricots & 0.088 & 0.721 \\
Tea & -0.089 & 0.504 \\
Coffee & -0.113 & 0.512 \\
Nescafe & -0.022 & 0.910 \\
Soft drinks & 0.042 & 0.812 \\
Cocoa & 0.133 & 0.666 \\
\hline Corits & \\
\hline
\end{tabular}

$\mathrm{r}=$ Correlation Coefficient.

$\mathrm{P}=$ Probability Value.

${ }^{*} \mathrm{P}<0.05=$ significant

Table (7):

Mean Values of Some Hormones and Calcium Concentrations in the Blood of Hyperthyroidism and HypothyroidismPatients.

\begin{tabular}{|c|c|c|c|c|}
\hline Groups & Hyperthyroidism $(n=40)$ & Hypothyroidism $(n=30)$ & \multirow{2}{*}{ Normal range } & \multirow{2}{*}{$\begin{array}{c}\mathrm{p} \\
\text { value }\end{array}$} \\
\hline Parameters & Mean \pm SD & Mean \pm SD & & \\
\hline $\mathrm{TSH}(\mathrm{ulU} / \mathrm{ml})$ & $0.7 \pm 0.8$ & $3.8 \pm 2.9$ & $0.27-4.2$ & $0.00001^{*}$ \\
\hline FT3(Pg/ml) & $3.9 \pm 1.1$ & $2.4 \pm 1.0$ & $2.00-4.4$ & $0.0001^{*}$ \\
\hline FT4(ng/dl) & $1.5 \pm 0.5$ & $1.0 \pm 0.2$ & $0.90-1.7$ & $0.0001^{*}$ \\
\hline Calcium(mg/dl) & $8.8 \pm 0.9$ & $8.9 \pm 0.8$ & $8.50-10.5$ & 0.686 \\
\hline
\end{tabular}

All data presented as mean \pm standard deviation.

${ }^{*} \mathrm{P}<0.001=$ High significant

$\mathrm{TSH}=$ thyroid stimulating hormone $\quad \mathrm{FT} 3=$ free triiodothronine

FT4= free thyroxine 


\section{Egypt. J. of Nutrition and Health Vol. 15 No. 1 January (2020)}

\section{References}

Al-Musa, H. (2017):

Impact of Obesity on Serum Levels of Thyroid Hormones among Euthyroid Saudi Adults, J. Thyroid Res., 2017: 5739806.

Armitage, G. and Berry, W. (1987):

Statistical methods $7^{\text {th }}$ Ed. Ames, lowa State University, Press. 39-63.

Balogh, E.; Paragh, G. and Jeney, V.(2018):

Influence of Iron on Bone Homeostasis, J. Pharmaceuticals (Basel), 11(4): 107.

Baltaci, A.; Mogulkoc, R. and Belviranli, M. (2013):

Serum levels of calcium, selenium, magnesium, phosphorus, chromium, copper and irontheir relation to zinc in rats with induced hypothyroidism, J. ActaClin Croat, 52:151-156.

Bassett, J. and Williams, G. (2016):

Role of Thyroid Hormones in Skeletal Development and Bone Maintenance, National Center for Biotechnology Information, U.S. National Library of Medicine, 37(2): 135-187.

Bhatnagar, S.; Srivastva, R.; Jahan, S. and Ranjan, R. (2017):

Multiple Effects of Hypothyroidism on Bone Mineral Density and Its Association with Vitamin D, Serum Calcium: A Cross-sectional Study, International Journal of Scientific Study,5(6):120124.

Bold, A. (1970):

Determinationof Calcium in Plasma;a Review of Some Modern Methods, I.nn.din.Biochem.,7: 131

Burckhardt, P. (2015):

Calcium revisited, part III: effect of dietary calcium on BMD and fracture risk, J. Bonekey Rep; 4: 708.

Caldwell, G.; Kellett, H.; Gow, S.; Beckett, G.; Sweeting, V.; Seth, J. and Toft, A. (1985):

A new strategy for thyroid function testing, Lancet, 1:1117.

Calsolaro, V.; Niccolai, F.; Pasqualetti, G.; Tognini, S.; Magno, S.; Riccioni, T.; Bottari, M.; Caraccio, N. and Monzani, F.(2018):

Hypothyroidism in the Elderly: Who Should Be Treated and How?, J. Endocr Soc. 3(1):146158.

Chee, W.; Suriah, A.; Chan, S.; Zaitun, Y and Chan, Y.(2003):

The effect of milk supplementation on bone mineral density in postmenopausal Chinese Women in Malaysia, J.Osteoporosis International,14: 828-834.

Closa, S.; Landeta, M.;Andérica, D.; Pighín, A. and Cufré, J. (2003):

Mineral Nutrient Content in Cow Milk and Dairy Products in Argentina, J. Arch LatinoamNutr., 53 (3): 320-4. 
Dai, Z and Koh, W. (2015):

B-Vitamins and Bone Health-A Review of the Current Evidence, J. Nutrients, 7 (5): 33223346.

Elbossaty, W. (2017):

Mineralization of Bones in Osteoporosis and Osteomalacia, J. Ann. Clin. Lab. Res., Vol.5, $4: 201$.

Farhangi, M.; Keshavarz, S.; Eshraghian, M.; Ostadrahimi, A. and Ali Saboor-Yaraghi, A. (2012): The Effect of Vitamin A Supplementation on Thyroid Function in Premenopausal Women, Randomized Controlled Trial, J. Am. Coll. Nutr., 31(4):268-74.

Farrow, E. and White, K. (2010):

Recent advances in renal phosphate handling, Nat Rev Nephrol, 6:207-217.

Ferro-Luzzi, A.; Sette, S.; Franklin, M. and James, W. (1992):

A simplified approach to assessing chronic energy deficiency. Eur. J. Clin. Nutr., 46: 173-186.

Gupta, G.; Sharma, P.; Kumar, P.; Itagappa, M. and Sharma, R. (2015):

A Correlation between Thyroid Stimulating Hormone and Body Mass Index in Women with Subclincal Hypothyroidism, Asian J. Pharm. Clin. Res., 8, (4): 206-208.

Hamlaoui, M.;Ayachi. A.; Dekaken, A. andGouri, A. (2018):

Relationship of metabolic syndrome and its components with thyroid dysfunction in Algerian patients, Diabetes Metal Syndr, 12(1):1-4.

Han, C.; Taira, K.; Yu, X. and Shen, H. (2005):

Nutritional Status Survey in 200 of the Korean and Han Nationality Elderly in Yanji, Wei Sheng Yan Jiu, 34(1):112-4.

Haugen, B. (2019):

The Effect of Vitamin A, Retinoids and Retinoid Receptors on the Hypothalamic-PituitaryThyroid Axis, ENDO, 22: 149-163.

Hill,J.; Wyatt,H. and Peters, J. (2012):

Energy Balance and Obesity, J. Circulation, 126(1): 126-132.

Janssen, I.; Homan, J.; Schijns, W.; Betzel, B.; Aarts, E.; Berends, F. and Boer, H. (2015):

Subclinical hypothyroidism and its relation to obesity in patients before and after Roux-en-Y gastric bypass, Surg Obes Relat Dis, 11(6):1257-63.

Jelliffe, D.B. (1966):

The Assessment of the Nutritional Status of the Community. WHO Monograph Series No. 56, WHO, Geneva. 


\section{Egypt. J. of Nutrition and Health Vol. 15 No. 1 January (2020)}

Kapoor, N.; Cherian, K.; Pramanik, B.; Govind, S.; Winford, M.; Shetty, S.; Thomas, N. and Paul, T. (2017):

Association between Dental Health and Osteoporosis: A Study in South Indian Postmenopausal Women, National Center for Biotechnology Information, U.S. National Library of Medicine, Journal of Mid-Life Health, 8(4): 159-162.

Kim, K.; Choi, S.; Lim, S.; Moon, J.; Kim, J.; Kim, S.; Jang, H. and Shin, C. (2014):

Interactions Between Dietary Calcium Intake and Bone Mineral Density or Bone Geometry in a Low Calcium Intake Population (KNHANES IV 2008-2010), J. Clin. Endocrinol Metab., 99(7):2409-17.

Kim, M.; Lee, J. and Johnson, M.(2015):

Poor Socioeconomic and Nutritional Status Are Associated With Osteoporosis in Korean Postmenopausal Women: Data from the Fourth Korea National Health and Nutrition Examination Survey (KNHANES) 2009, J. Am Coll. Nutr; 34 (5): 400-7.

Kim, Y.; Kim, K.; Lim, S.; Choi, S.; Moon, J.; Kim, J.; Kim, S.; Jang, H. and Shin, C. (2015): Favorable Effect of Dietary Vitamin C on Bone Mineral Density in Postmenopausal Women (KNHANES IV, 2009): Discrepancies Regarding Skeletal Sites, Age, and Vitamin D Status,J. Osteoporos Int, 26(9):2329-37.

Kong, S.; Kim, J.; Hong, A.; Lee, J.; Kim, S. and Shin, C. (2017):

Dietary Potassium Intake Is Beneficial to Bone Health in a Low Calcium Intake Population: The Korean National Health and Nutrition Examination Survey (KNHANES) (2008-2011), J. Osteoporos Int ., 28 (5): 1577-1585.

Kwon, D.; Park, H.; Cho, Y.; Kim, K. and Kim, N. (2020):

Different Associations of Socioeconomic Status on Protein Intake in the Korean Elderly Population: A Cross-Sectional Analysis of the Korea National Health and Nutrition Examination Survey, J. Nutrients,12(1): 10.

Lee, S.; Kim, K.; Lee, E.; Song, M.; Kang, D.; Kim, H.; Youm,Y.; Yun, Y.; Park, H.; Kim, C. and Rhee, Y.(2016):

Low Normal TSH levels are Associated with Impaired BMD and Hip Geometry in the Elderly, National Center for Biotechnology Information, U.S. National Library of Medicine, Aging and Disease, 7(6): 734-743.

Ma, Q.; Liang, M.; Wang, Y.; Ding,N.; Wu, Y.; Duan, L.; Yu, T.; Yanzhu Lu, Y.; Xu, J.; Kang, F. and Dou, C. (2020):

Non-coenzyme Role of Vitamin $B_{1}$ in RANKL-induced Osteoclastogenesis and Ovariectomy Induced Osteoporosis, J Cell Biochem.

Markwald, R.; Melanson, E.; Smith, M.; Higgins, J.; Perreault, L.; Eckel, R. and Wright, K. (2013): Impact of insufficient sleep on total daily energy expenditure, food intake, and weight gain, Proc Natl. Acad. Sci. U S A, 110(14): 5695-5700. 
Messer, J.; Kilbarger, A.; Erikson, K. and Kipp, D. (2009):

Iron overload alters iron-regulatory genes and proteins, down-regulates osteoblastic phenotype, and is associated with apoptosis in fetal rat calvaria cultures, J. Bone, vol. 45 , no. 5, pp. 972-979.

Mishra, S.; Goldman, J.;Sahyoun, N. and Moshfegh, A. (2018):

Association between dietary protein intake and grip strength among adults aged 51 years and over: What We Eat in America, National Health and Nutrition Examination Survey 2011-2014, J. PLoS One,13(1): e0191368.

Nygaard, B. (2015):

Hyperthyroidism in pregnancy, BMJ. Clin. Evid., 2015: 0611.

Oh, C. and No, J. (2017):

Does Protein Intake Affect Metabolic Risk Factors Among Older Adults in Korea?, J. Obes. Metab. Syndr., 26(4):266-273.

Orchard, T.; Larson, J.; Alghothani, N.; Bout-Tabaku, S.;Cauley, J.; Chen, Z.; LaCroix, A.; Wactawski-Wende, J. and Jackson, R. (2014):

Magnesium intake, bone mineral density, and fractures: results from the Women's Health Initiative Observational Study, Am. J. Clin. Nutr., 99(4): 926-933.

Pepa, G. and Brandi, M. (2016):

Microelements for bone boost: the last but not the least, J. Clin. Cases. Miner Bone Metab., 13(3): 181-185.

Pignotti, G.; Vega-López, S.; Keller, C.; Belyea, M.; Ainsworth, B.; Williams, A.; Records, K.; Coonrod, D. and Permana, P. (2015):

Comparison and Evaluation of Dietary Quality Between Older and Younger MexicanAmerican Women, Public Health Nutr., 18(14):2615-24.

Polito, A.; Intorre, F.; Andriollo-Sanchez, M.; Azzini, E.; Raguzzini, A.; Meunier, N.; Ducros, V.; O'Connor, J.; Coudray, C.; Roussel, A. and Maiani, G. (2005):

Estimation of Intake and Status of Vitamin A, Vitamin E and Folate in Older European Adults: The ZENITH, Eur. J. Clin. Nutr., 59(2):S42-7.

Qu, X.; Zihao He, Z.; Qiao, H.; Zhai, Z.; Mao, Z.; Yu, Z. and Daia, K.(2018):

Serum copper levels are associated with bone mineral density and total fracture, J. OrthopTranslat, 14: 34-44.

Rizzoli, R. (2014):

Dairy Products, Yogurts, and Bone Health, Am. J. Clin. Nutr., 99 (5): 1256S-62S.

Rizzoli, R.; Bischoff-Ferrari, H.; Dawson-Hughes, B. andWeaver, C. (2014):

Nutrition and bone health in women after the menopause, J. Womens Health (Lond), 10(6):599-608. 


\section{Egypt. J. of Nutrition and Health Vol. 15 No. 1 January (2020)}

Sahni, S.; Tucker, K.; Kiel, D.; Quach, L.; Casey, V. and Hannan, M. (2013):

Milk and yogurt consumption are linked with higher bone mineral density but not with hip fracture: the Framingham Offspring Study, J. Arch. Osteoporos, 8(0): 119.

Sakurai, M.; Nakagawa, H.; Kadota, A.; Yoshita, K.; Nakamura, Y.; Okuda, N.; Nishi, N.; Miyamoto, Y.; Arima, H.; Ohkubo, T.; Okamura, T.; Ueshima, H.; Okayama, A. and Miura, K. (2018):

Macronutrient Intake and Socioeconomic Status: NIPPON DATA2010, J. Epidemiol, 3(3):S17S22.

Sharifi, N.; Majlessi, F.; Montazeri, A.; Shojaeizadeh, D. and Sadeghi, R. (2017):

Prevention of osteoporosis in female students based on the Orem self-care model, National Center for Biotechnology Information, U.S. National Library of Medicine,Electron Physician, 9(10): 5465-5471.

Sharma, R.; Sharma, P.; Kumar, P. and Gupta, G. (2016):

ROLE OF MAGNESIUM IN POST-MENOPAUSAL WOMEN WITH OSTEOPOROSIS AND OSTEOPENIA, Asian J. Pharm. Clin. Res., 9, 1, 198-199.

Solanki, A.; Bansal, S.; Jindal, S.; Saxena, V. and Shukla, U. (2013):

Relationship of serum thyroid stimulating hormone with body mass index in healthy adults, Indian J. Endocrinol Metab., 17(Suppl1): S167-S169.

Vannucci, L.; Fossi, C.; Quattrini, S.; Guasti, L.; Pampaloni, B.; Gronchi, G.; Giusti, F.; Romagnoli, C.; Cianferotti, L.; Marcucci, G. and Brandi, M. (2018):

Calcium Intake in Bone Health: A Focus on Calcium-Rich Mineral Waters, J. Nutrients, 10(12): 1930.

Wang, Y.; Dellatore, P.; Douard, V.; Qin, L.; Watford, M.; Ferraris, R.; Tiao Lin, T. and Shapses, S.(2016):

High fat diet enriched with saturated, but not monounsaturated fatty acids adversely affects femur, and both diets increase calcium absorption in older female mice, J. Nutr. Res., 36(7): 742-750.

Weaver, C. (2013):

Potassium and Health, J. Adv. Nutr., 4(3): 368S-377S.

WHO (World Health Organization) Expert Committee (2004):

Appropriate body mass index for Asian populations and its implications for policy and intervention strategies. The Lancet, 2004; 157-163.

Willett, W. and Lenart, E. (1998):

Reproducibility and validity of food-frequency questionnaires. In: Willett W, editor. Nutritional Epidemiology. 2th ed. Oxford, New York: Oxford University Press; 1998. pp. 101-47.

Williams, G. and Bassett, J. (2018):

Thyroid diseases and bone health, Journal of Endocrinological Investigation, 41(1):99-109. 


\title{
Hoda S. Ibrahim, et al
}

Yamada, T.; Kurasawa, S.; Matsuzaki, M. and Tanaka, A. (2013):

Increase in skimmed milk intakes brings positive calcium balances during body weight reduction by exercise, FASEB J. Vol. 27, No. 1.

Yamasaki, K. and Hagiwara, H. (2009):

Excess iron inhibits osteoblast metabolism, Toxicology Letters, 191(2-3); 211-215.

Yazdanpanah, N.; Zillikens, M.; Rivadeneira, F.; Jong, R.; Lindemans, J.; Uitterlinden, A.; Pols,H. and Meurs, J. (2007):

Effect of Dietary B Vitamins on BMD and Risk of Fracture in Elderly Men and Women: The Rotterdam Study, J. Bone, 41 (6): 987-94.

Zabriskie, H.; Currier, B.; Harty, P.; Stecker, R.; Jagim, A. and Kerksick, C. (2019):

Energy Status and Body Composition Across a Collegiate Women's Lacrosse Season, J. Nutrients, 23;11(2)

Zhao, Y.; Song, Y.; Zhang, L.; Zheng, F.; Wang, X.; Zhuang, X.; Wu, F. and Liu, J. (2020): Association between bile acid metabolism and bone mineral density in postmenopausal women, J. Clinics Sao Paulo, 75: e1486.

\section{تقييم الحالة الغذائية للسيدات اللاتى يعانين من خلل في الغذة الدرقية وهشاشة العظام}

\section{ا.د/هلى سلامه أبراهيم*، د/عحمد مجدى غيط**، نيفين محمود عبد العظيم*}

\author{
*قمم التغذية و علوم الأطعمة ، كلية الاقتصاد المنزلي ، جامعة حلوان

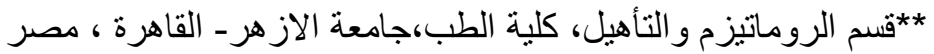 \\ الملخص العربي
}

\begin{abstract}
هناشة العظام وإضطر ابات الغذة الدرقية من الأمر اض الثائعة لاى كبار السن. هدفت الدراسة الي تقييم الحالة الغذائية للنساء اللآتي

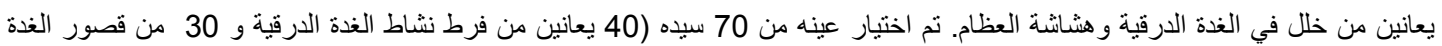

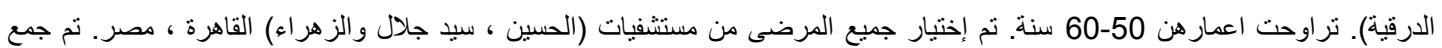

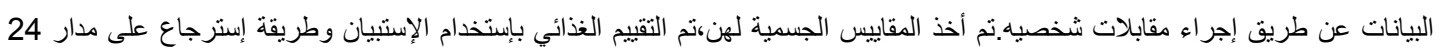

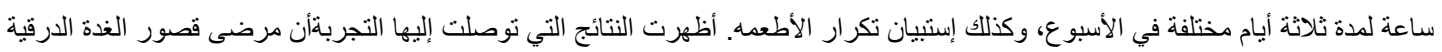

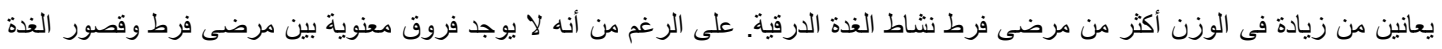

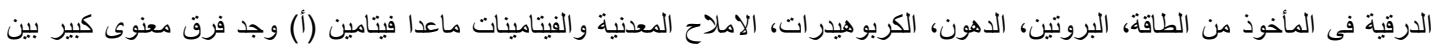

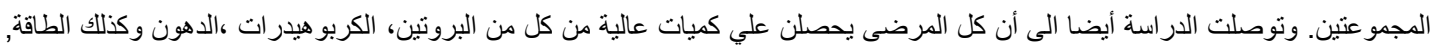

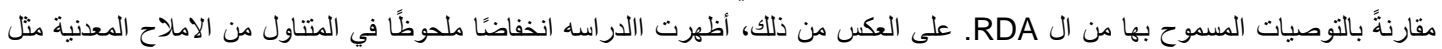

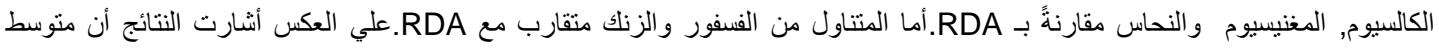

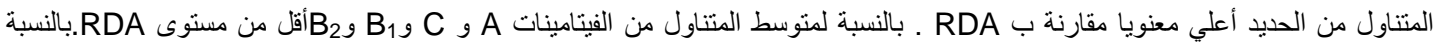

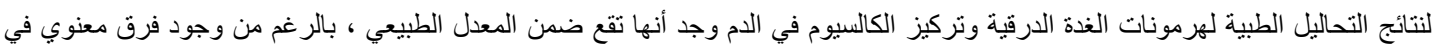

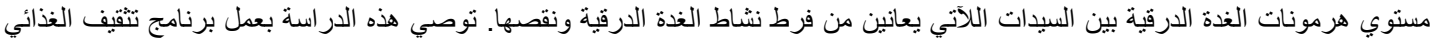

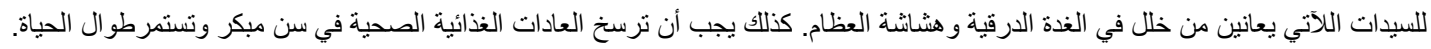
الكلمات المفتاحية:التقييم الغذائي، خلل الغذة الدرقية، هثاشة العظام، الكتناول من المغذيات.
\end{abstract}

